\title{
The influence of environmental factors on obesity in children up to 7 years old
}

\author{
${ }^{1}$ Aneta Czerwonogrodzka-Senczyna, ${ }^{1}$ Paulina Kryńska, ${ }^{2}$ Anna Majcher, ${ }^{2}$ Małgorzata Rumińska, \\ ${ }^{1}$ Anna Jeznach-Steinhagen, ${ }^{2}$ Beata Pyrżak
}

'Zakład Żywienia Człowieka, Warszawski Uniwersytet Medyczny, ${ }^{2}$ Klinika Pediatrii i Endokrynologii, Warszawski Uniwersytet Medyczny

Adres do korespondencji:

Aneta Czerwonogrodzka-Senczyna, Warszawski Uniwersytet Medyczny, Zakład Żywienia Człowieka, ul. Ciołka 27, 01-445 Warszawa, e-mail: aneta.czerwonogrodzka@wum.edu.pl

Słowa kluczowe: otyłość, dzieci, dieta

Key words: obesity, children, diet

\section{STRESZCZENIE/ABSTRACT}

\begin{abstract}
Wstęp. Problem otyłości coraz powszechniej dotyczy dzieci najmłodszych. Szacuje się, że w Polsce nadwaga bądź otyłość cechuje ponad 12\% dzieci. Przyczyny otyłości są złożone, ale najczęściej spowodowana jest ona niewłaściwym stylem życia całej rodziny. Problem otyłości u najmłodszych nie powinien być bagatelizowany przez rodziców i lekarzy pediatrów. Otyłe dziecko może pozostać otyłym dorosłym i jest $\mathrm{w}$ większym stopniu narażone na dolegliwości ze strony narządów ruchu, układów: pokarmowego, sercowo-naczyniowego, oddechowego niż jego szczupli rówieśnicy. Cel pracy. Analiza wpływu wybranych czynników środowiskowych na występowanie otyłości u dzieci do 7 roku życia. Material i metody. Badaniem objęto 33 dzieci w wieku od 2 do 7 lat. U każdego pacjenta oceniono masę i wysokość ciała, wyliczono wskaźnik masy ciała (BMI, body mass index), który wystandaryzowano według średniej (X) i odchylenia standardowego (SD) dla populacji dzieci warszawskich. Za kryterium włączenia przyjęto rozpoznaną przez lekarza otyłość prostą (BMI $\geq 2$ SDS). Wśród rodziców/opiekunów dzieci przeprowadzono wywiad obejmujący dane o: spożyciu produktów i potraw z ostatnich 48 godzin, nawykach żywieniowych rodziny, stopniu aktywności fizycznej dziecka, urodzeniowej masie ciała, sposobie i czasie karmienia w niemowlęctwie, występowaniu otyłości w rodzinie. Oceny jadłospisu dokonano w podgrupach (1-3 i $4-7$ lat). Uzyskane wyniki porównano do odpowiednich norm żywieniowych. Wyniki. Średnia BMI w SDS badanej grupy wyniosła 4,76 $\pm 1,97$. U ponad 70\% dzieci przynajmniej jedno z rodziców miało otyłość, u $21 \%$ oboje. Wysoką masę urodzeniową rozpoznano u 11 badanych, $53 \%$ pacjentów było karmionych piersią $\geq 6$ miesięcy. W grupie 1-3 lata wartość energetyczna diety realizowała $156 \%$ normy, w grupie 4-7 lat-108\%. Prawie 67\% dzieci, spożywało dosładzane napoje, tj. soki, herbatki, wodę smakową, napoje typu cola. Żywność typu fast-food m.in. raz w tygodniu spożywało ponad 12\% badanych. Większość badanych (67\%) deklarowała średnią lub wysoką aktywność fizyczną. Jadłospisy pacjentów deklarujących wysoką aktywność fizyczną charakteryzowały się istotnie niższą wartością energetyczną. Wnioski. Głównymi czynnikami wpływającymi na występowanie otyłości u dzieci było spożywanie znacznych ilości dosładzanych napojów. Dodatkowe obciążenie stanowiła nadmierna masa ciała rodziców, wiążąca się z niewłaściwym stylem życia całej rodziny. Endokrynol. Ped. 13/2014;2(47):17-24.
\end{abstract}


Introduction. The problem of obesity concern more commonly children since the earliest years. It is estimated that in Poland over $12 \%$ of children distinguish themselves in the overweight or obesity. The reasons of obesity are complex, most often it is caused by the wrong lifestyle of the family. The problem of obesity of the youngest kids is very often belittled by parents and paediatricians. The obese kid, much more then his slim peers, is endangered with the ailments from the musculoskeletal system, gastrointestinal tract, cardiovascular system and respiratory system, during the childhood, as well as in the adult life. Objectives. the analysis of the chosen social factors on obesity of children up to 7 years old. Materials and methods. The research covers 33 children from age 2 to 7 years. Each patient's body weight and height have been measured and the body mass index (BMI), standardized on the average and standard deviation (SD) of the population of Warsaw children, has been calculated. Among the parents and carers the questionnaire has been carried out about their dietary habits, level of physical activity of their child, the birth body weight, way and time of breast feeding, obesity occurrence in the family. The diets have been assessed in 2 groups (1-3 and 4-6 years old). The results have been compared with the appropriate dietary standards. Results. The average SDS BMI of the researched group came to $4,76 \pm 1,97$. At least one parent was obese in the $70 \%$ of cases, both parents at $21 \%$ of patients. Almost $67 \%$ of children have consumed sweetened beverages, as: juices, teas, water beverages and others like coca-cola. In the group of 1-3 years old the dietary nutritional value implemented $156 \%$ of the standard, whilst in the group of 4-6 years old - 108\% of the standard. More then $12 \%$ of the patients have consumed fast foods at least ones a week. The diets of patients declaring more physical activity have been characterized by the subtantial lower energy value. Conclusions. The main factor influencing the children obesity is consumption of the significant amount of sweetened beverages. Additional burden is the parents' excessive body weight, linked with the wrong life style of the whole family. Pediatr. Endocrinol. 13/2014;2(47):17-24.

\section{Wstęp}

Problem nadwagi i otyłości dotyczy $12 \%$ dzieci w Polsce [1]. Częstość występowania nadmiernej masy ciała wśród najmłodszych ma charakter wzrostowy. W Polsce stale przybywa dzieci z nadwagą w wieku 5-11 lat [2].

Niedożywienie wewnątrzmaciczne płodu i niska masa urodzeniowa noworodka trwale zmieniają jego metabolizm, ,przeprogramowując” organizm na tryb oszczędzania zasobów energetycznych i mogą przyczynić się do powstawania otyłości w wieku późniejszym [3, 4]. Obciążone ryzykiem rozwoju otyłości są również noworodki urodzone $\mathrm{z}$ masą ciała $4000 \mathrm{~g}$ [5].

Część autorów uważa, że wysoka masa ciała w okresie niemowlęcym może zwiększać ryzyko występowania otyłości w późniejszym wieku [6]. Jednak nie wszystkie badania są zgodne i wykazują opisywaną tendencję [7].

Sposób karmienia we wczesnym okresie życia dziecka wpływa na jego masę ciała w czasie dojrzewania i dorosłości. Niemowlęta karmione w sposób naturalny przez sześć lub więcej miesięcy wykazywały mniejszą tendencję do nadwagi i otyłości w późniejszym wieku niż dzieci karmione mlekiem modyfikowanym $[8,9]$.

W okresie wczesnego dzieciństwa największy wpływ na kształtowanie nawyków żywieniowych dziecka mają rodzice i opiekunowie [3]. Zjawisko przekarmiania dzieci przez rodziców jest dość czę- ste [10]. Powszechnie występuje przekonanie matek o niewystarczającej ilości spożywanych posiłków przez dzieci i postrzeganiu ich jako niejadki [11].

$\mathrm{U}$ dzieci starszych istotnym problemem wydaje się wzrastające spożycie produktów typu fast-food [12]. Obok produktów, które są serwowane w tego typu restauracjach, rośnie spożycie przez dzieci dosładzanych napojów, które stanowią znaczący udział energii $w$ ich diecie [13].

Częstym zjawiskiem wśród otyłych dzieci jest przewaga wartości energetycznej diety $\mathrm{w}$ drugiej połowie dnia [3], wynikająca $\mathrm{z}$ pomijania pierwszego oraz drugiego śniadania oraz podjadania pomiędzy posiłkami [14]. Duży wpływ na jakość przekąsek zdaje się mieć asortyment sklepików szkolnych [15].

Obecnie często rodzice zawożą dzieci do szkoły samochodem, pozbawiając je w ten sposób spaceru. Ponadto dzieci preferują spędzanie wolnego czasu oglądając telewizję, grając $\mathrm{w}$ gry komputerowe, zamiast uczestniczenia $\mathrm{w}$ zabawach $\mathrm{z}$ rówieśnikami. Nawet dzieci w wieku przedszkolnym i młodsze oglądają telewizję kilka godzin dziennie $[16,17]$.

Nadmierna masa ciała rodziców jest ważnym czynnikiem ryzyka rozwoju otyłości u ich dzieci. Wykazano, iż ryzyko wystąpienie nadwagi u dziecka było większe w przypadku nadwagi u obojga rodziców. Nieprawidłowa masa ciała u jednego z rodziców niosła stosunkowo mniejsze ryzyko rozwinięcia się otyłości u dziecka [18]. 


\section{Cel pracy}

Celem pracy była analiza wpływu wybranych czynników środowiskowych na występowanie nadmiernej masy ciała u dzieci do 7 roku życia, a w szczególności ocena: sposobu żywienia, wpływu aktywności fizycznej, zależności pomiędzy urodzeniową masą ciała a otyłością, wpływu sposobu i długości karmienia w okresie niemowlęcym na występowanie otyłości, zależności między nadmierną masą ciała występującą u rodziców a otyłością u badanych dzieci.

\section{Materiał i metody}

Badaniem objęto 33 dzieci (14 chłopców, 19 dziewczynek) w wieku od 2 do 7 lat $(4,85 \pm 1,39$ lat), z czego większość (73\%) uczęszczała do przedszkoli. Badani byli pacjentami Kliniki Pediatrii i Endokrynologii, Samodzielnego Publicznego Dziecięcego Szpitala Klinicznego w Warszawie. Za kryterium włączenia do badania przyjęto rozpoznaną przez lekarza otyłość prostą.

U każdego pacjenta wykonano badanie lekarskie, pomiary antropometryczne masy i wysokości ciała, na podstawie których wyliczono wskaźnik masy ciała (BMI, body mass index), który wystandaryzowano według średniej (X) i odchylenia standardowego (SD, standard deviation) dla populacji dzieci warszawskich (19). BMI w SDS $\geq(+) 2$ klasyfikowano jako otyłość.

Do realizacji badania wykorzystano jadłospis z ostatnich 48 godzin. W przypadku, gdy sposób żywienia różnił się w tych dniach od zwyczajowego, wywiad poszerzano o pytania dodatkowe pozwalające odwzorować model zwyczajowego żywienia. W wywiadzie uwzględniono również nawyki żywieniowe rodziny, aktywność fizyczną i masę urodzeniową badanego oraz sposób i czas karmienia $\mathrm{w}$ okresie niemowlęcym, a także występowanie otyłości w rodzinie. Badanie lekarskie, pomiary antropometryczne oraz wywiad żywieniowy przeprowadzono w pierwszej dobie hospitalizacji.

Oceny diety dokonano z zastosowaniem Tabel sktadu i wartości odżywczej produktów i potraw [20]. W ocenie wielkości porcji posłużono się Albumem fotografii produktów i potraw [21].

W celu oceny sposobu żywienia badani zostali podzieleni na dwie podgrupy, według zastosowanych norm żywieniowych [22]. Grupa pierwsza $(n=9)$ obejmowała dzieci w wieku od 1 do 3 lat, grupa druga $(\mathrm{n}=24)$ dzieci w wieku od 4 do 7 lat. Dla porównania wartości składników odżywczych z normami posłużono się zalecanym dziennym spożyciem na dany składnik odżywczy (RDA, Recommended Dietary Allowance), oprócz sodu, potasu, wapnia oraz witamin D i E, dla których użyto norm obejmujących wystarczające dzienne spożycie (AI, Adequate Intake). Dane analizowano jako procent realizacji norm dla każdego pacjenta i składnika pokarmowego. Wyniki uśredniono dla poszczególnych grup wiekowych.

Aktywność fizyczną badanych oceniono przyjmując za: niską aktywność fizyczną - aktywność w ciągu dnia bez dodatkowych zajęć sportowych; średnią aktywność fizyczną - 1-2 godziny tygodniowo dodatkowych zajęć sportowych; wysoką aktywność fizyczną - 3 i więcej godzin tygodniowo dodatkowych zajęć sportowych.

Za małą masę urodzeniową noworodka uznano wartość poniżej $2500 \mathrm{~g}$, za prawidłową 2500-3999 $\mathrm{g}$, za wysoką $\geq 4000 \mathrm{~g}$ [23].

Oceny nadmiaru masy ciała u rodziców dokonano w oparciu o pomiary masy i wysokości ciała, wyliczając wskaźnik BMI. Uzyskane wartości interpretowano według kryteriów WHO [24].

Analizę statystyczną przeprowadzono z użyciem programu Statistica 9.0 PL. Za poziom istotności statystycznej przyjęto wartość wskaźnika p-Value $<0,05$.

\section{Wyniki}

Średnie BMI w SDS w całej badanej grupie wyniosło $4,76 \pm 1,97$. U 21,2\% badanych wskaźnik ten był $\geq 6$ (ryc. 1).

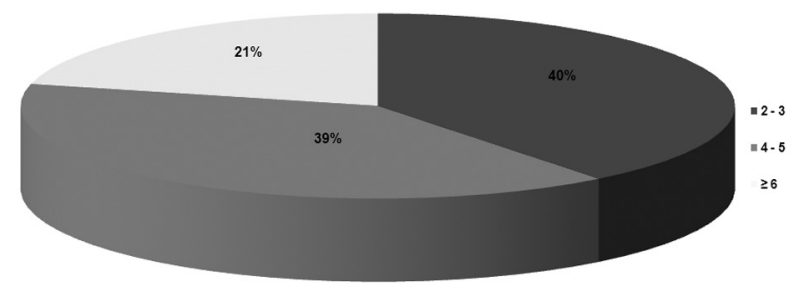

Ryc. 1. Odsetek badanych w zależności od wartości BMI w SDS

Fig. 1. Percentage of subjects, depending on the value of $B M I S D S$ 
Średnia masa urodzeniowa wyniosła $3626,4 \pm$ $683,3 \mathrm{~g}$. Wysoką mase urodzeniową rozpoznano u 11 badanych (34,4\%), a niską u 2 osób (6,3\%).

Odsetek dzieci karmionych piersią $\geq 6$ miesięcy wyniósł ponad 53\% (n=17). Przez okres krótszy niż 6 miesięcy karmionych naturalnie było $25 \%(n=9)$ badanych. Odsetek dzieci niekarmionych nigdy piersią wyniósł prawie $22 \%(n=7)$. Nie stwierdzono istotnej zależności $(\mathrm{p}>0,05)$ między długością karmienia piersią, masą urodzeniową a stopniem otyłości.

Analiza jadłospisów dzieci wykazała, iż w grupie 1-3 lata zostało zrealizowane $156 \%$ normy na energię (mediana $1556 \mathrm{kcal} /$ dobę). W grupie 4-7 lat odsetek ten wyniósł 108\% (mediana $1516 \mathrm{kcal} /$ dobę).

W grupie 1-3 lata mediana zawartości białka w diecie wyniosła $63 \mathrm{~g}$ (314\% normy zalecanego dziennego spożycia), natomiast węglowodanów 213 g (164\% normy). Najwyższa zawartość węglowodanów w dietach tej grupy wiekowej wyniosła 373 g. W grupie 4-7 lat wartości te kształtowały się następująco: ilość białka w diecie $68 \mathrm{~g}$ (ponad $262 \%$ zalecanego dziennego spożycia), węglowodanów 199 g (153\% normy). Najwyższa zawartość białka w diecie w tej grupie wyniosła $123 \mathrm{~g}$, co prawie czterokrotnie przekraczało zalecenia. Zawartość tłuszczów w jadłospisach w obu grupach wiekowych nie odbiegała od norm.

Analizie poddano również strukturę spożycia węglowodanów zawartych $\mathrm{w}$ diecie badanych dzieci z wyróżnieniem zawartości laktozy, skrobi, sacharozy i błonnika pokarmowego (ryc. 2). Mediana zawartości $\mathrm{w}$ diecie sacharozy $\mathrm{w}$ grupie 1-3 lata wyniosła ponad $57 \mathrm{~g}$ (norma $25 \mathrm{~g}$; najwyższy wynik 161g). Zawartość w jadłospisach błonnika pokarmowego wyniosła $13 \mathrm{~g}$ (norma 6-8 g). W grupie 4-7 lat spożycie sacharozy przekroczyło $61 \mathrm{~g}$ (norma 35g; najwyższy wynik $174 \mathrm{~g}$ ), zaś błonnika pokarmowego $16 \mathrm{~g}$ (norma 9-11 g).

U wszystkich badanych wykazano znaczne niedobory witaminy D w diecie: $\mathrm{w}$ grupie 1-3 lata zaobserwowano jej spożycie na poziomie $20 \%$ wystarczającego dziennego spożycia, w grupie 4-7 lat $26 \%$, oraz niedobory retinolu kolejno: $62 \%$ i $70 \%$ normy. W przypadku grupy 4-7 lat stwierdzono również niewystarczające spożycie folianów (77\% realizacji normy).

Głównym spożywanym płynem w ciągu doby przez prawie $67 \%$ badanych były dosładzane napoje. Odsetek dzieci spożywających głównie naturalną, bezsmakową wodę wyniósł ok. 33\%. Spożycie soku owocowego jako głównego napoju przez badanych $w$ ciągu dnia deklarowało ponad $36 \%(n=14)$ ich rodziców/opiekunów. Jedna osoba przyznała, iż podstawowym płynem spożywanym przez dziecko był napój typu cola (ryc. 3).

Spożycie żywności typu fast-food w badanej grupie dzieci deklarowało ponad $12 \%$ rodziców $(n=4)$. Osoby te odwiedzały restauracje serwujące tego typu żywność m.in. raz w tygodniu. Zaobserwowa-

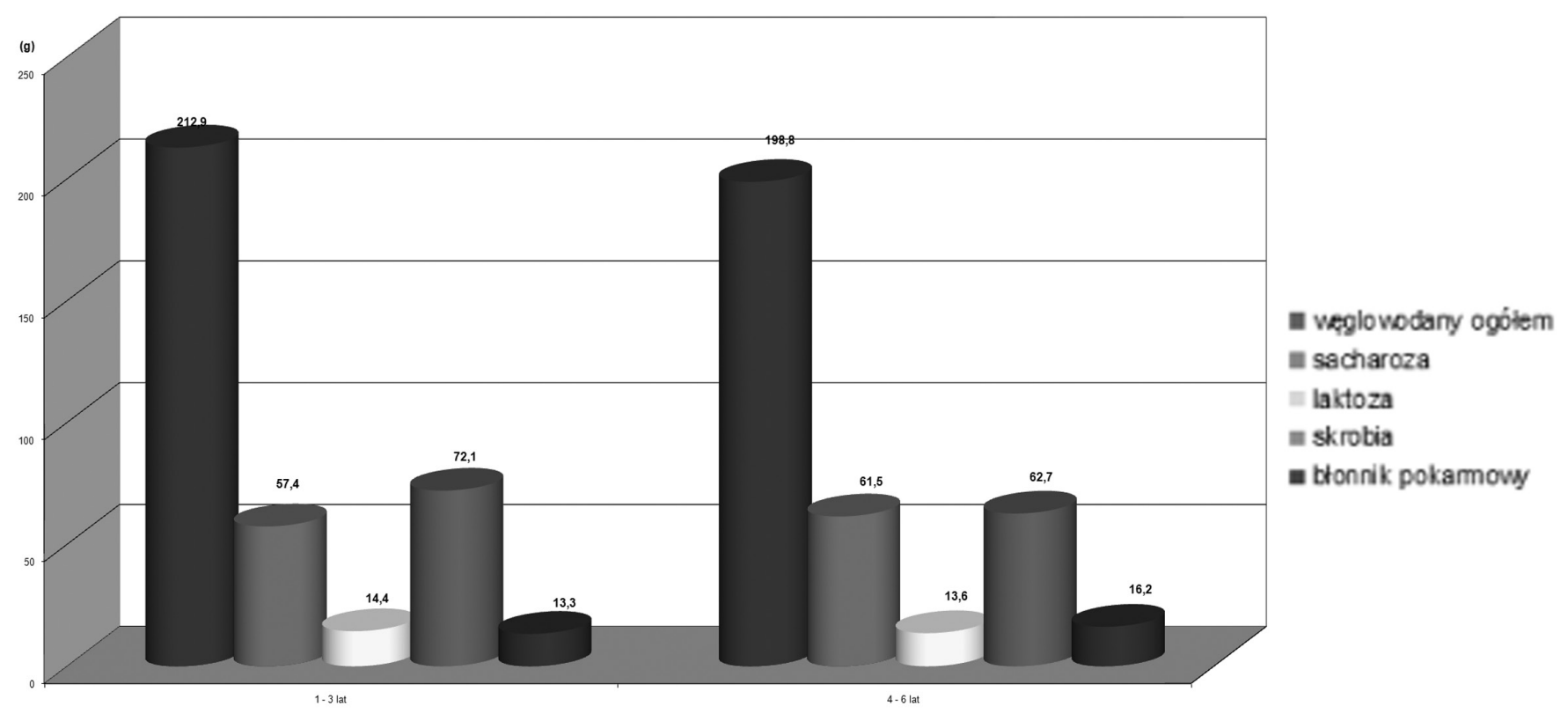

Ryc. 2. Struktura i mediana zawartości węglowodanów w dietach badanych

Fig. 2. The structure and median carbohydrates in the children diets 


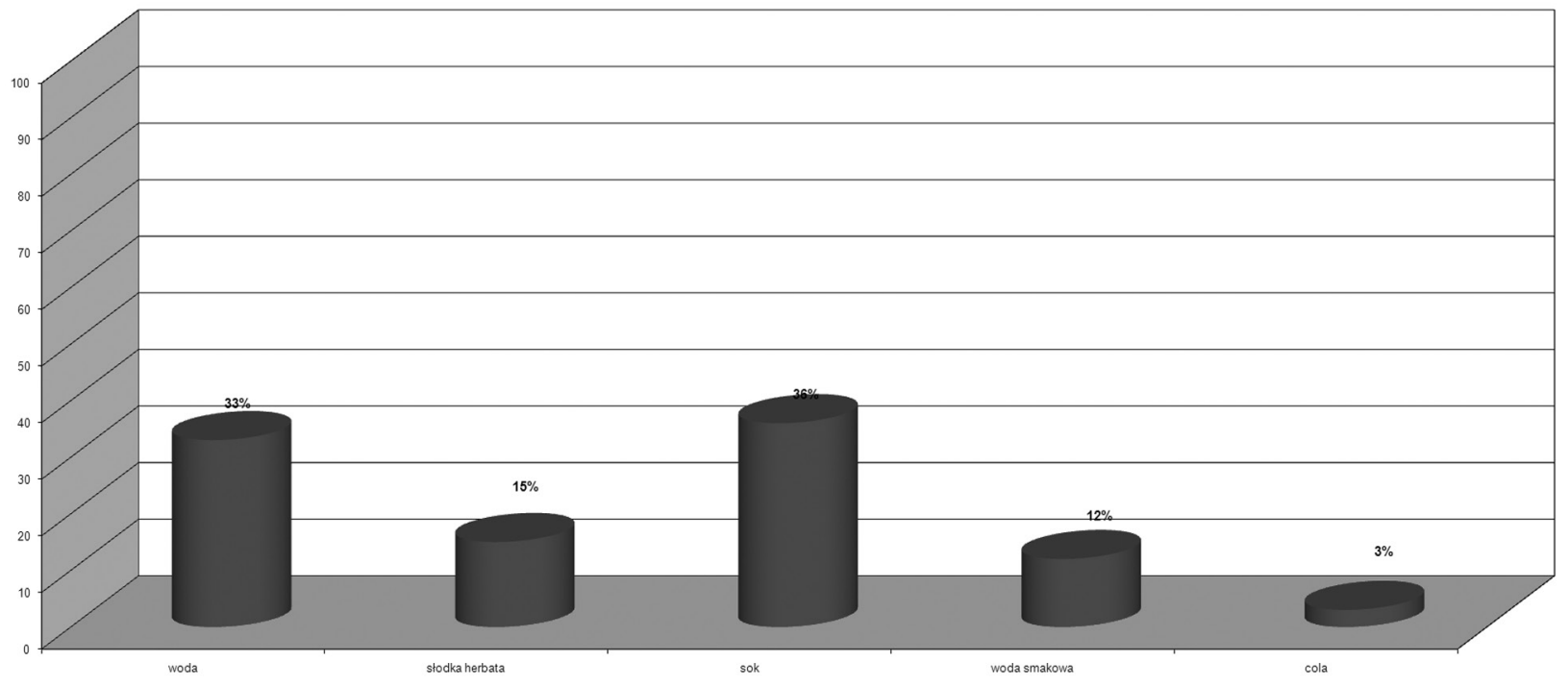

Ryc. 3. Odsetek osób spożywających różne rodzaje napojów

Fig. 3. The percentage of children who consume different types of beverages

no również znaczną nieregularność w konsumpcji posiłków oraz częste podjadanie między nimi batonów, słodkich bułek i serków twarogowych, rzadziej owoców. Dzieci uczęszczające do przedszkola często konsumowały dwa posiłki obiadowe.

Odsetek badanych o niskiej aktywności fizycznej wyniósł średnio 33\% $(\mathrm{n}=11)$. Pozostali pacjenci deklarowali średnią $(36,4 \%)$ bądź wysoką aktywność $(30,3 \%)$. Jadłospisy pacjentów, których rodzice deklarowali niską aktywność fizyczną, charakteryzowały się wyższą wartością energetyczną niż diety dzieci o wysokim jej stopniu (mediana: 1638,8 kcal vs. $1339,9 \mathrm{kcal} ; \mathrm{p}=0,09$ ) (ryc. 4), zawierały także więcej tłuszczów i sacharozy. Jednak nie wykazano statystycznie istotnych różnic w BMI w SDS w tych grupach badanych $(3,64$ vs. $3,61, p>0,05)$.

Analizie poddano także występowanie otyłości wśród rodziców pacjentów. Odsetek badanych, u których chociaż jedno z rodziców miało otyłość, wyniósł prawie $70 \%(n=23)$. Otyłość u obojga rodziców stwierdzono u ponad $21 \%$ badanych $(n=7)$. Wykazano, że występowanie otyłości u co najmniej jednego $\mathrm{z}$ rodziców istotnie statystycznie dodatnio korelowało ze wskaźnikiem masy ciała u dzieci ( $\mathrm{r}$ $=0,37 ; \mathrm{p}=0,04)$

\section{Dyskusja}

Etiopatogeneza otyłości jest złożona, ale obserwowana narastająca liczba dzieci $\mathrm{z}$ nadwagą i otyłością w ciągu ostatnich dekad świadczy

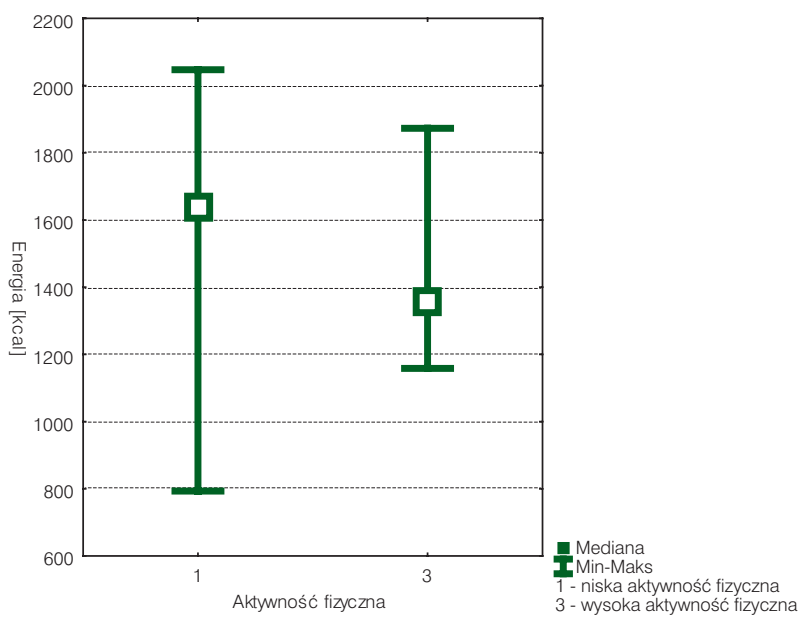

Ryc. 4. Różnica w wartości energetycznej diet badanych w zależności od stopnia aktywności fizycznej Fig. 4. The difference in the energy value of the tested diets according to the degree of physical activity

o istotnym wpływie czynników środowiskowych na jej powstawanie. Ich rola zaznacza się już od okresu prenatalnego. Niektórzy autorzy wskazują na wpływ wysokiej masy urodzeniowej na rozwój otyłości w wieku późniejszym, zarówno u chłopców, jak i dziewczynek [5]. Zjawisko to thumaczone jest nieodwracalnym rozrostem tkanki thuszczowej w okresie wczesnego dzieciństwa [3]. $\mathrm{Z}$ kolei inne badania wykazały korelację pomiędzy niską masa urodzeniową noworodka a rozwojem otyłości. Fakt ten tłumaczony jest zjawiskiem trybu oszczędzania energii w przypadku niedosta- 
tecznych zasobów energetycznych, co wiąże się $\mathrm{z}$ trudnościami w utrzymaniu optymalnej masy ciała w przyszłości [4]. Wyniki badań własnych nie wykazały zależności pomiędzy masą urodzeniową badanych a stopniem nadmiaru masy ciała, być może tendencja ta będzie bardziej widoczna w wieku późniejszym.

W badaniach własnych nie stwierdzono wpływu sposobu i długości karmienia w okresie niemowlęcym na występowanie otyłości. Długość karmienia naturalnego u ponad połowy badanych była wyższa niż 6 miesięcy. Scott i wsp. [8] udowodnili, że karmienie w sposób naturalny przez więcej niż 6 miesięcy zmniejszało ryzyko występowania otyłości w wieku późniejszym. Waksmańska i wsp. [9] zwrócili uwagę na podobną zależność.

Łoś-Rycharska i Niecławska [11] wykazały, że rodzice często przekarmiają swoje dzieci. W badaniu własnym znaczne odchylenia od normy, dotyczące wartości energetycznej, stwierdzono w grupie 1-3 lata. Badani realizowali $156 \%$ normy na energię. W grupie 4-7 lat nie stwierdzono znaczących odchyleń od zaleceń. W diecie występowała znaczna ilość węglowodanów prostych zawartych $\mathrm{w}$ napojach oraz w słodyczach. W badaniu przeprowadzonym przez Lasater i wsp. [13] z udziałem dzieci w wieku od 6 do 11 lat, wykazano, iż od roku 1989 do roku 2008 wartość energetyczna (kcal) pochodząca $\mathrm{z}$ dosładzanych napojów wzrosła ze 130 do $212 \mathrm{kcal}$ na osobę, a $\mathrm{z}$ produktów mlecznych dosładzanych i pełnotłustych z 28 do $63 \mathrm{kcal}$ na osobę. Dzieci w tej grupie wiekowej zaczęły spożywać więcej soków, napojów owocowych i słodkich napojów gazowanych (z 67\% do $77 \%$ ) oraz pełnotłustych i słodkich produktów mlecznych (z 19\% do 39\%). Badania przeprowadzone na Krecie [25], w których analizowano jadłospisy 856 dzieci w wieku 4-7 lat, dowiodły, że niemal $60 \% \mathrm{z}$ nich piło codziennie słodkie napoje. Ponadto stwierdzono małą podaż wapnia, witamin A i E, spowodowaną niskim udziałem mleka i jego przetworów oraz warzyw i owoców w codziennym żywieniu. Dzieci, w których diecie zaobserwowano najwyższe spożycie słodkich napojów, cechowały się wyższym wskaźnikiem masy ciała i obarczone były dwukrotnie większym ryzykiem rozwoju otyłości niż pozostali uczestnicy badania. Wzrastające spożycie tych napojów jest niepokojące, ponieważ może przyczyniać się do powstawania dodatniego bilansu energetycznego, a to z kolei do nadwagi i otyłości, zarówno w dzieciństwie, jak i w dorosłym życiu.
Dzieci coraz częściej spożywają żywność typu fast-food. Wykazano, iż 2,5\% dzieci w okresie poniemowlęcym spożywało ten rodzaj żywności przynajmniej raz w miesiącu, zaś $11,5 \%$ dzieci w wieku przedszkolnym minimum raz $\mathrm{w}$ tygodniu. $\mathrm{W}$ badaniu własnym ponad $12 \%$ dzieci spożywało żywność typu fast-food min. raz w tygodniu, głównie w weekendy [12].

Niewłaściwe zachowania żywieniowe, objawiające się nieregularnym spożywaniem posiłków, również zaobserwowano w niniejszym badaniu. Dzieci uczęszczające do przedszkola (4-7 lat) często spożywały dwa obiady. Zaobserwowano także częste pojadanie pomiędzy posiłkami produktów, jak batony, słodkie bułki, serki, rzadziej owoce. W badaniu Roszko-Kirpszy i wsp. [14] odnotowano, że nieregularne spożywanie posiłków występowało u ponad $20 \%$ badanych dzieci. Z kolei Szymandera-Buszka i wsp. [15] wykazali, że dzieci pojadały głównie produkty typu lizaki, słodycze oraz chipsy.

W badaniu Jodkowskiej i wsp. [26] stwierdzono, iż dzieci w wieku szkolnym, u których występowała otyłość istotnie częściej niż dzieci z prawidłową masą ciała deklarowały raczej małą aktywność fizyczną. $\mathrm{W}$ badaniu własnym ponad $60 \%$ pacjentów deklarowało średnią lub wysoką aktywność fizyczną. Uwagę zwraca jednak prawdopodobny fakt zatajania przez rodziców rzeczywistej ilości spożywanych produktów i potraw przez dzieci z wysokim stopniem nadwagi. Ich rodzice zazwyczaj deklarują, że dziecko jada bardzo mało, przy czym jest bardzo ruchliwe. Znajduje to odzwierciedlenie w wynikach badań własnych. Dzieci o najwyższej aktywności fizycznej miały istotnie niższą wartość energetyczną diety niż pacjenci nieuprawiający sportów, przy czym nie zauważono istotnych różnic w zakresie wskaźnika BMI w SDS.

Występowanie otyłości u co najmniej jednego rodzica dodatnio, istotnie statystycznie $(p=0,04)$ wpływało na stopień otyłości u dziecka. Zależność ta może wskazywać na genetyczne predyspozycje, ale co istotniejsze - na niewłaściwy styl życia rodziny $[5,17]$.

Edukacja z zakresu przyczyn występowania otyłości, zasad zdrowego żywienia i zmian stylu życia nie tylko dzieci, ale całych rodzin jest w naszym kraju konieczna. Rodzice zgłaszający się do ośrodków zajmujących się rozpoznawaniem i leczeniem otyłości u dzieci bardzo często informują o kłopotach w uzyskaniu dostępu do specjalisty oraz bagatelizowaniu problemu przez lekarzy pediatrów. $\mathrm{Z}$ obserwacji wynika również niestety, iż nadmiar 
masy ciała szczególnie u dzieci najmłodszych często nie jest przedmiotem troski nie tylko lekarzy pediatrów, ale również rodziców [27].

\section{Wnioski}

1. Otyłość u dzieci poniżej 7 roku życia staje się zjawiskiem powszechnym.

2. Okres karmienia piersią i masa urodzeniowa niemowląt nie wpływały na występowanie otyłości u badanych, ale jej rozwój w tak krótkim okresie życia może wskazywać na istotną rolę nieprawidłowych zwyczajów żywieniowych rodziny.
3. Przyczyn otyłości u badanych można upatrywać w nadkonsumcji pożywienia, na co wskazywało przekroczenie norm na energię i w znacznym stopniu na białko oraz węglowodany.

4. Istotnym czynnikiem, który mógł wpłynąć na występowanie otyłości u dzieci było spożywanie znacznych ilości dosładzanych napojów oraz podjadanie między posiłkami.

5. Niska aktywność fizyczna dzieci prawdopodobnie zwiększała częstość podjadania.

6. Występowanie otyłości u dzieci było związane z występowaniem nadmiernej masy ciała rodziców.

\section{REFERENCES/PIŚMIENNICTWO}

[1] Jarosz M.: Epidemiologia otyłości wśród dzieci i dorosłych. Zwalczanie otyłości i innych przewlekłych chorób niezakaźnych. Instytut Żywności i Żywienia, Warszawa 2008: http://www.izz.waw.pl [cytowano: 01.10.2012].

[2] International Obesity Task Force. European Union Platform Briefing Paper. Brussels, 15 March 2005: www.iaso.org [cytowano: 30.11.2012].

[3] Tounian P.: Otyłość u dzieci. PZWL, Warszawa 2008.

[4] Gruszfeld D., Dobrzyńska A., Socha P. et al.: Programowanie żywieniowe otyłości i zespołu metabolicznego. Stand. Med., 2008,5: 159-163.

[5] Mazur A., Klimek K., Małecka-Tendera E.: Czynniki ryzyka występowania otyłości u dzieci szkolnych w województwie podkarpackim. Endokrynol. Otyłość, 2011,3: 157-166.

[6] Baird J., Fisher D., Lucas P. et al.: Being big or growing fast: systematic review of size and growth in infancy and later obesity. BMJ, 2005:331, 929-931.

[7] Esposito-De Puente A., De Filippo E., Caldara A. et al.: Determinants of body fat in prepubertal age. Minerva Pediatr., 1993:45, 383388.

[8] Scott J.A., Nq S.Y., Cobiac L.: The relationship between breastfeeding and weight status in a national sample of Australian children and adolescents. BMC Public Health, 2012:12, 107.

[9] Waksmańska W., Łukasik R., Mikulska M. et al.: Ocena rozwoju fizycznego czteroletnich dziewczynek z miasta Bielsko-Biała w aspekcie wybranych czynników rodzinno-środowiskowych. Pediatr. Pol., 2011:86, 624-629.

[10] Scott J.: Development of food preferences in early childhood. Nutridate, 2011:22, 1-10, http://www.nhs.vic.edu.au [cytowano: 22.11.2012].

[11] Łoś-Rycharska E., Niecławska A.: Odżywiania dzieci w wieku poniemowlęcym i przedszkolnym w ocenie ich matek. Pediatr. Pol., 2010:85, 588-596.

[12] Łoś-Rycharska E., Niecławska A.: Spożycie pokarmów typu fast-food przez dzieci w wieku poniemowlęcym i przedszkolnym. Pediatr. Pol., 2010:85, 345-352.

[13] Lasater G., Piernas C., Popkin B.M.: Beverage patterns and trends among school-aged children in the US, 1989-2008. J. Nutr., 2011:10, 103.

[14] Roszko-Kirpsza I., Olejnik B.J., Zalewska M. et al.: Wybrane nawyki żywieniowe a stan odżywienia dzieci i młodzieży regionu Podlasia. Probl. Hig. Epidemiol., 2011:92, 799-805.

[15] Szymandera-Buszka K., Waszkowiak K., Jędrusek-Golińska A. et al.: Ocena asortymentu sklepików w szkołach miasta Poznań. Probl. Hig. Epidemiol., 2010:91, 628-631.

[16] Oblacińska A., Weker H. (red).: Profilaktyka otyłości u dzieci i młodzieży od urodzenia do dorosłości. Wydawnictwo Help-Med., Kraków 2008.

[17] Wardle J., Carnell S.: Parental feeding practices and children's weight. Acta Pediatr., 2007:96, 5-11.

[18] Jodowska M., Oblacińska A., Tabak I. et al.: Nadwaga i otyłość rodziców i ich 13-letnich dzieci w Polsce. Przegl. Epidemiol., 2011:65, 497-502.

[19] Palczewska l., Niedźwiecka Z.: Wskaźniki rozwoju somatycznego dzieci i młodzieży warszawskiej. Med. Wieku Rozw., 2001:5, 1854.

[20] Kunachowicz H., Nadolna I., Przygoda B. et al.: Tabele składu i wartości odżywczej żywności. PZWL, Warszawa 2005.

[21] Jarosz M., Buthak-Jahymczyk B.: Normy żywienia dla ludności Polski - tabele zbiorcze. Wydawnictwo Lekarskie PZWL, Warszawa 2008 
[22] Szponar L., Wolnicka K., Rychlik E.: Album fotografii produktów i potraw. Instytut Żywności i Żywienia, Warszawa 2000.

[23] Mazur A., Klimek K., Małecka-Tendera E.: Czynniki ryzyka występowania otyłości u dzieci szkolnych w województwie podkarpackim. Endokrynol. Otyłość, 2011:3, 157-166.

[24] Szczygieł B.: Pogłębiona ocena stanu odżywienia. Badania antropometryczne. W: Niedożywienie związane z chorobą. Red. B. Szczygiet, Wydawnictwo Lekarskie PZWL, Warszawa 2011, 43.

[25] Linardakis M., Sarri K., Pateraki M.S. et al.: Sugar-added beverages consumption among kindergarten children of Crete: effects on nutritional status and risk of obesity. BMC Public Health, 2008, 8: 279

[26] Jodowska M., Tabak I., Oblacińska A.: Aktywność fizyczna i zachowania sedenteryjne gimnazjalistów z nadwagą i otyłością w Polsce w 2005 r. Probl. Hig. Epidemiol., 2007:88, 149-156.

[27] Majcher A., Czerwonogrodzka-Senczyna A., Bielecka-Jasiocha J. et al.: Rozwój otyłości we wczesnym dzieciństwie - obserwacje własne. Probl. Hig. Epidemiol., 2011:92, 241-246. 